\title{
Outros 500 - O Quinto Centenário de Timor-Leste e o Pós-Colonialismo em Português
}

\author{
Daniel de Lucca \\ Universidade da Integração Internacional da Lusofonia Afro-Brasileira - UNILAB, \\ São Francisco do Conde, Bahia, Brasil \\ E-mail:dandelucca@gmail.com
}




\section{Resumo}

Este artigo propõe uma análise ritual dos "500 anos" de Timor-Leste a partir de imagens e de narrativas oficiais veiculadas em função da efeméride. O objetivo é lançar um olhar antropológico para essa produção, tratando-a como faces de um único evento ritual aqui tomado como posto de observação privilegiado para interrogar tanto o processo de formação do Estado-nação em TimorLeste quanto o pós-colonialismo em português. Argumenta-se que os significados mobilizados nessas comemorações, inspiradas em modelos rituais de tradição colonial, só podem ser adequadamente compreendidos a partir da análise e da articulação de diferentes camadas de tempos históricos. Ao final, propõe-se uma leitura em contraponto das celebrações dos "500 anos" de Timor-Leste e do Brasil, de modo a localizá-las no interior do "espaço lusófono", noção que só pode ser abordada de modo crítico.

Palavras-chave: Timor-Leste. 500 anos. História. Nação. Pós-colonialismo em Português.

\section{Abstract}

This article proposes a ritual analysis of the "500 years" of Timor-Leste from official images and narratives conveyed in function of the celebrations. The aim is to throw an anthropological look at this production, treating it as the faces of a single ritual event here as a privileged observation post to interrogate both the process of nation-state formation in Timor-Leste and post-colonialism in Portuguese. I argue that the meanings mobilized in these celebrations, inspired by ritual models of colonial tradition, can only be adequately understood from the analysis and articulation of different layers of historical times. In the end, I propose a counter-reading of the events of the "500 years" of Timor-Leste and Brazil, so as to locate them within the "lusophone space", a notion that can only be approached in a critical way.

Keywords: Timor-Leste. 500 years. History. Nation. Post-colonialism in Portuguese. 


\section{Redescobrindo o Passado}

To ano de 2015 o português Rui Correia propôs inaugurar uma 1 nova rota de viagem de Portugal para a ilha de Timor. O site LisboaDili, criado para divulgar o projeto e angariar doações e patrocínios, apresentava o novo viajante como uma figura que "desde muito novo ouviu as histórias de aventura de Serpa Pinto, explorador que mapeara o hinterland africano ligando as costas do Atlântico ao Índico, lendo todos os seus relatos e literatura de viagens e descobertas". Diz ainda que ele tinha "ansiedade de partir e conhecer outros povos, outras gentes e o fascínio da aventura e das grandes viagens". Inspirado nas explorações do império português oitocentista, esse expedicionário do século XXI propunha então um novo desafio: “a primeira ligação terrestre entre Lisboa e Díli, usando como meio de transporte uma moto".

Assim explicava os motivos e os sentidos da expedição.

Timor-Leste, a primeira nação do terceiro milênio, é um Estado insular que desde sempre viveu em grande isolamento, resultante da sua condição geográfica. Este isolamento foi reforçado pela imposição de obstáculos à livre circulação durante os 24 anos de ocupação indonésia. A viagem pretende vencer o mito do isolamento de Timor que muitos consideram longe de tudo, perdido nos confins de mundo, espaço insular de difícil acesso e ligação aos restantes territórios e países do mundo que não seja por via aérea ou marítima. Para vencer este mito o trajecto proposto pretende fazer a ligação por terra, atravessando o continente asiático e a Europa desde o seu extremo ocidental com recurso apenas a travessias relativamente curtas de ferry-boat. A viagem será a primeira ligação direta entre Portugal e a parte mais longínqua do mundo lusófono. (Correia, 2015) 
Romper barreiras, vencer mitos, acessar ao longínquo isolado, ir do centro do mundo lusófono à sua mais distante periferia: tal era o desafio colocado pelo projeto. O percurso, que durou 3 meses e atravessou 18 países, buscava também associar dois tempos históricos: o ano de 1515 e o de 2015. A chegada do viajante lusitano "aos confins do mundo" coincidia intencionalmente com o momento ápice das comemorações oficiais dos "500 anos da chegada dos portugueses" na ilha de Timor. Com isso, a expedição não era apenas um deslocamento no espaço, mas também uma forma de regressar no tempo. A empreitada transcontinental era a atualização de um evento ocorrido meio milênio antes, também um modo de redescobrir um passado glorioso de aventuras e, mais que isso, uma forma de recontá-lo por meio de uma nova história de viagem.

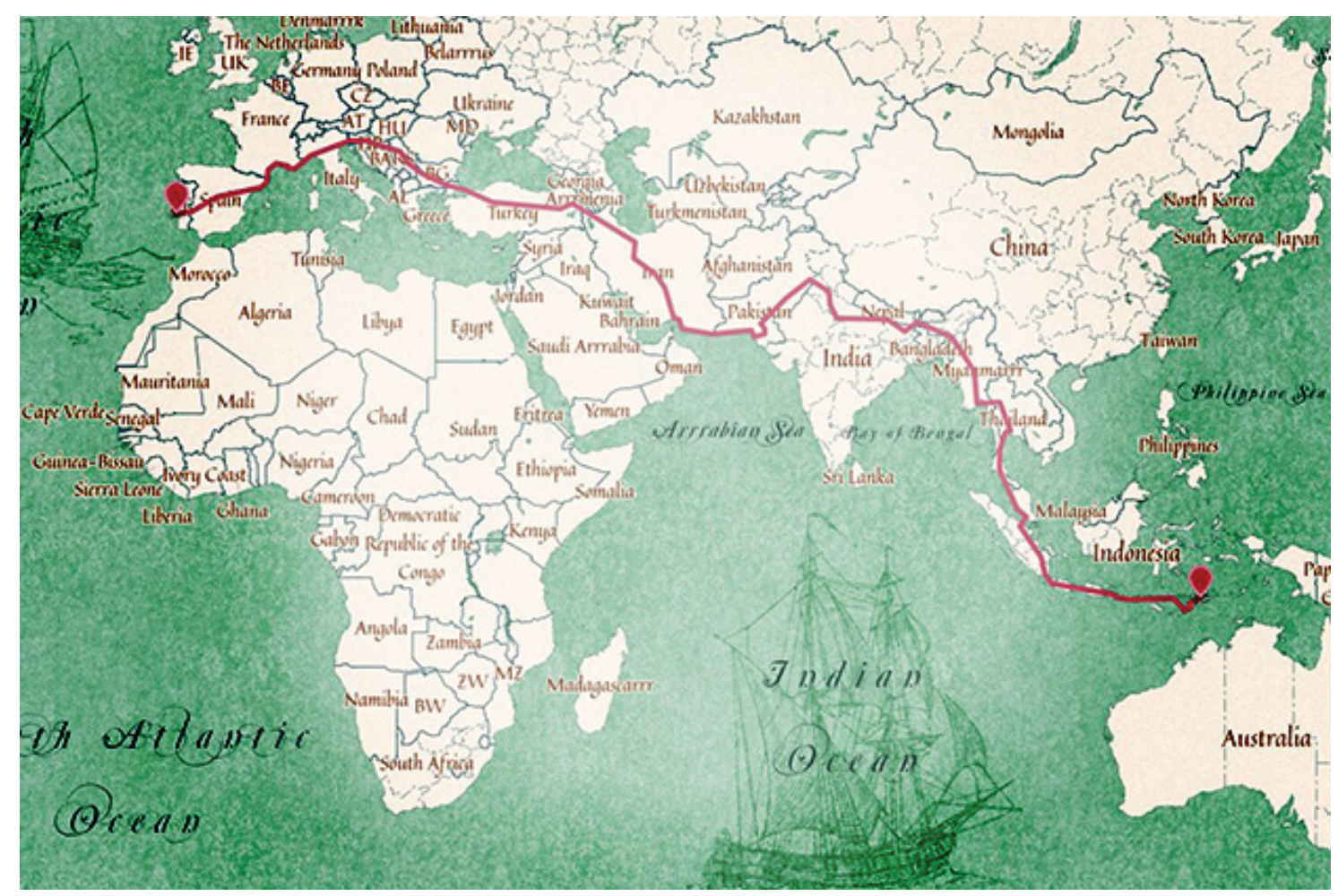

Figura 1: Viagem feita de moto por Rui Correia, em 2015, e divulgada no site LisboaDíli. No mapa, alegorias às navegações marítimas em verde dialogam com a rota terrestre traçada em vermelho Fonte: Correa (2015)

Neste artigo proponho uma análise das celebrações dos "500 anos" de Timor-Leste a partir de imagens e narrativas oficiais veiculadas em função da efeméride. Entre 2012 e 2014, vivi e trabalhei como professor na capital de Timor-Leste, Díli, contexto no qual desenvolvi pesquisa 
de campo para minha tese de doutorado (De Lucca, 2016) ${ }^{1}$. No ano de 2015, retornei ao país para aprofundar minha investigação, mas não presenciei as principais atividades das comemorações aqui descritas. Assim, esta análise não resulta de uma etnografia direta do evento, mas é informada por esta minha experiência de campo. Proponho então, um mapeamento das práticas e discursos oficiais produzidos em função das comemorações, considerando depoimentos, materiais e documentos visuais que circularam na mídia, sites e blogs. O objetivo é lançar um olhar antropológico para esta produção, de modo a tratá-la em conjunto, como faces de um único e grande evento ritual. Considero este ritual, público e transnacional, como um posto de observação adequado para interrogar tanto o processo de formação do Estado-nação em Timor-Leste quanto o pós-colonialismo em português (Almeida, 1999; 2007), uma noção que se volta para o "espaço lusófono" de forma não essencialista e permite questionar a repetição ritual dos "descobrimentos" numa perspectiva descentrada e diaspórica.

De maneira muito geral, o pós-colonialismo tende a ser tratado numa dupla acepção não excludente: histórica e teórica (Hall, 2003; McClintock, 2010). Na primeira chave, destaca-se a reconfiguração global de poder decorrente do fim do colonialismo, a construção dos Estados independentes, as crises nacionais e a rearticulação de alianças regionais. Na segunda acepção, acentua-se seu caráter crítico, na exegese textual e performática das antigas histórias coloniais e nacionais, bem como na leitura, descentrada e diaspórica, dos processos de subalternização e silenciamento envolvidos na constituição de identidades. Sem abandonar as contribuições colocadas por essa segunda linha, dou especial atenção aos significados propriamente históricos do termo. Neste sentido, este trabalho dialoga com a proposta de uma "antropologia do legado colonial" (L'Estoile, 2008) ou mesmo de uma "antropologia da história" (Gonçalvez, 2017), na medida em que analiso tensões existentes entre distintas representações da história e do passado colonial. Para fazer emergir tais tensões, proponho uma articulação entre três camadas de tempos históricos distintos que se superpõe, se interpelam e foram referenciadas nos "500 anos" de Timor-Leste: o século XVI, marco histórico do "contato" lembrado e comemorado; 
as três últimas décadas do século XX, contexto de desenvolvimento do nacionalismo timorense, intensificado com ocupação indonésia; e o próprio início do século XXI, momento pós-independência no qual as celebrações foram realizadas.

O fim do século XIX constitui uma quarta camada histórica relevante para o entendimento dos "500 anos" de Timor-Leste. Entretanto, com exceção das explorações oitocentistas que inspiraram a expedição de moto Lisboa-Díli acima comentada, este período não foi destacado no desenrolar das comemorações. É nesse momento histórico que as celebrações centenárias dos "descobrimentos" foram inventadas como verdadeiros espetáculos públicos que mobilizaram aparelhos de Estado, intelectuais, meios de comunicação e o consumo das massas (Hobsbawm, 1988). Tal modelo ritual, de tradição colonial, apresenta inúmeras semelhanças com as comemorações que tiveram lugar em Timor-Leste no ano de 2015.

Filhas da era dos impérios, as comemorações dos "descobrimentos" constituíram um gênero particular de festividade no qual os antigos impérios europeus e os novos Estados americanos reivindicaram e contestaram posições geopolíticas e pertencimentos civilizacionais a partir da encenação e afirmação pública de uma história colonial comum (Monteiro; Thomaz, 1996). Tais práticas mostraram-se cruciais para a formação da própria ideia de Europa moderna, cristalizando o discurso do expansionismo europeu como história única e inaugural. Tal violência epistêmica impôs aos não europeus as rubricas de "povos pré-históricos" ou mesmo "sem história", desconsiderando também o fato de que no século XV "africanos chegaram à Ásia, os indianos à África, os árabes à China. Navegantes indianos passam pelo Cabo da Boa esperança e adentram o Atlântico por volta de 1420" (Shohat; Stam, 2006, p. 99). Assim, a hegemonia do euroimperialismo passou a estruturar a geografia e o tempo histórico global, destituindo o protagonismo do mundo extra-europeu e colocando-o numa "sala de espera": primeiro a Europa, depois o resto. Como bem argumentou Henrique Dussel (1994), a narrativa dos "descobrimentos", ainda hoje, encerra um "encobrimento" muito maior, o do outro.

Mas se os "descobrimentos" desempenharam um papel central nas representações da modernidade ocidental, Portugal teve aí uma 
participação singular, na medida em que foi a primeira potência europeia a lançar-se na expansão e também a que manteve por mais tempo seu império. Mas seu declínio, iniciado em fins do século XVI e aprofundado com a perda do Brasil, em 1822, promoveu mudanças de localização do império português na economia política envolvente, assinalando “[...] uma progressiva transformação do primeiro grande império mercantil em poder subalterno" (Feldman-Bianco, Almeida; Bastos, 2007, p. 16). Essa sua posição o levará ao paradoxo do "excesso de colonialismo e déficit de capitalismo" (Santos, 2003, p. 25), visto que no contexto da Conferência de Berlim, a economia portuguesa mal sustentava a nova política colonial de inserção do Estado e do racismo científico em territórios até então mantidos por frágeis alianças locais e pela dependência dos poderes autóctones.

Em Portugal, a narrativa dos "descobrimentos" condensa significados cuja gênese de sua estrutura mítica pode ser encontrada na obra de Camões. Tal matriz discursiva foi impulsionada pela euforia nacional-imperialista do republicanismo finissecular do oitocentos, período de crise da monarquia frente ao "ultimato britânico" e a perda dos territórios na África Austral. Na luta pela afirmação territorial do império, "guerras de pacificação" foram travadas contra poderes africanos e asiáticos, fazendo avançar a presença colonial portuguesa (até então mais circunscrita às margens costeiras de seus domínios) em direção ao maior controle sobre as terras interiores e as autoridade locais. Assim, apenas na segunda metade do século XIX é que o “Timor Português", um território periférico de um império europeu secundário, passou a ser objeto de alguma colonização organizada, podendo antes disso ser melhor caracterizado como um "entreposto comercial" ou mesmo um "protetorado" (Thomaz, 2001; Pélisser, 1996; Gunn, 1999). Dada a distância, a pobreza e o prejuízo atribuído ao território insular à época, foram formuladas inúmeras propostas de "venda" e "troca" da colônia com outras potências. Contudo, "os portugueses não queriam Timor por causa de seu presente. Eles estavam lá por causa do passado" (Roque, 2010, p. 5). O passado mítico das "grandes navegações" fornecia legitimidade e sentido à presença portuguesa na longínqua Insulíndia pois, como vestígio daquele tempo glorioso, reforçava o princípio sagrado 
que dominava a política portuguesa de então: o caráter inalienável dos territórios do império cujo "direito histórico" deveria remontar à "era dos descobrimentos".

No decorrer do século XX, a ideologia do Estado Novo reforçou o projeto imperial e o mito da predestinação portuguesa de "dar novos mundos aos Mundo". Com o fim da Segunda Guerra Mundial e o início dos tempos de descolonização o conceito de "Império Colonial Português" foi abolido da legislação e do discurso oficial em favor da exaltação de um "Portugal uno, do Minho ao Timor", cujos diversos espaços configurariam uma só nação "multirracial e pluricontinental" (Thomaz, 2002). A propaganda salazarista estabeleceu novos nomes e intensificou algumas velhas práticas, como as comemorações do "quinto centenário da descoberta da Guiné" celebrada em 1947 naquele território. Mas com a Revolução dos Cravos e o desmonte do "Ultramar", em 1974, o tema dos "descobrimentos" foi temporariamente silenciado para voltar com energia total em 1986, ano que foi criada da Comissão Nacional para as Comemorações dos Descobrimentos Portugueses (CNCDP).

Em fins do século $\mathrm{XX}$, o imperativo eurocêntrico inscrito nas práticas da referida Comissão chegou a promover constrangimentos além mar. Como em 1988, num de seus primeiros atos, por ocasião da celebração dos "500 anos" da passagem de Bartolomeu Dias pelo Cabo da Boa Esperança. Com apoio oficial do apartheid, a performance da chegada da caravela numa praia whites-only, contracenada por atores brancos que representavam "indígenas africanos" por meio do blackface, foi boicotada por ativistas sul-africanos críticos ao regime racista (Jugular, 2013). Já no ano de 2000, a Comissão integrou, num de seus últimos atos, as comemorações dos "500 anos do descobrimento do Brasil". Concentrados no litoral Sul da Bahia, na região que a partir de então foi rebatizada como "Costa dos Descobrimentos", as celebrações brasileiras foram fortemente contestadas pelos movimentos sem-terra, negro e indígena. A resposta imediata do governo Fernando Henrique Cardoso foi o aparato policial, reprimindo violentamente as manifestações contrárias ao ritual proposto pelo Estado (Silva, 2003). Mesmo com a desmobilização da CNCDP em Portugal, o tema dos "descobrimentos" continuou vivo século XXI adentro. Em 2009, o livro de um jornalista 
australiano foi traduzido para o português e se tornou alvo de grande atenção pública em Portugal. Com pouco rigor documental a obra reforçava a mitologia lusíada defendendo a tese de que "a Austrália foi descoberta pelos portugueses", alguns anos depois de Timor e cerca de 250 anos antes de James Cook mapear o continente austral. Na ocasião, seu autor foi alvo de honrarias acadêmicas e científicas, chegando a receber do governo português a condecoração da Comenda da Ordem do Mérito (Pinto, 2014). Nos três contextos meridionais referidos nestes cerimoniais (África do Sul, Brasil e Austrália) observa-se a primazia narrativa do fardo do homem branco lusitano em detrimento das perspectivas dos outros "encobertos": africanos, ameríndios e aborígenes.

Ainda hoje o debate público português permanece apresentando uma avaliação positiva da expansão, dos descobrimentos e do colonialismo ${ }^{2}$. Esta continuidade institucional a-crítica "do culto aos descobrimentos" foi nomeada por Silvia Maeso como "loop pós-colonial", um conceito derivado da linguagem de programação de computadores que evidencia uma "estrutura de repetição" cujas instruções, sob certas condições, são executadas indeterminadamente (Maeso, 2016). Importantes museus, monumentos, livros didáticos e cerimoniais diversos em Portugal continuam a ritualizar o momento genético de formação do império português. Isso, em detrimento de uma reflexão aprofundada sobre o "Terceiro Império Colonial" e os eventos críticos que acabaram por instaurar a divisória pós-colonial: o racismo de Estado, uso do trabalho forçado nas colônias, a falta de democracia na metrópole, as guerras coloniais em África e o trauma dos colonos retornados (Castelo, 2006).

A importância dos rituais na construção dos impérios e das nações já foi sublinhada por diversos autores e se encontra no centro de algumas teorizações antropológicas sobre as formas do Estado e do poder no Sudeste Asiático (Geertz, 1991; Scott, 1976; Tambiah, 1985). Também os estudos etnológicos sobre Timor-Leste, que o localizam na área cultural da "Indonésia Oriental" (Eastern Indonesia), destacaram a relevância da produção ritual de laços sociais e simbólicos com os antepassados (Fox, 1980; Roque, 2010; Traube, 1986). Aqui, meu desejo é explorar 
as formas nas quais a narrativa dos "descobrimentos" foi apropriada e mimetizada nos "500 anos" de Timor-Leste como uma estratégia para reafirmar sua posição na esfera nacional e internacional. Isso, pois o momento ápice das comemorações foi programado para coincidir com o aniversário de 40 anos da proclamação da independência da República Democrática de Timor-Leste (RDTL). O ritual de Estado buscava relembrar, num único gesto, dois momentos aparentemente contraditórios: a gênese do laço colonial e sua ruptura. Como então compreender uma cerimônia que festeja a independência ao mesmo tempo em que comemora o início da presença colonizadora? Como interpretar a vinculação festiva da libertação política com o advento da dominação europeia na ilha?

\section{Produzindo o Tempo Histórico}

A documentação sobre a presença portuguesa em Timor no início do século XVI é frágil. A data exata do desembarque português na ilha não é clara e, inclusive, não há registros que confirmem com precisão o desembarque no ano de 1515 (Thomaz, 1994; Gunn, 1999). Uma primeira representação da ilha, na cartografia ocidental, data de 1512 e breves citações sobre Timor podem ser identificadas em importantes obras da literatura de viagem seiscentista portuguesa: a Suma Oriental de Tomé Pires, o Livro de Duarte da Costa e Os Lusíadas de Luiz Vaz de Camões, trabalhos que sempre referenciam a ilha em função do sândalo, componente nativo de interesse comercial. Na literatura ocidental, a primeira descrição explícita da vida na ilha é de António Piagafetta que, lá chegando em expedição espanhola, no ano de 1522, faz alusão à existência da maladie portugaise, "[...] doença venérea que apenas poderia ter sido transmitida por viajantes vindos do 'Novo Mundo', ou noutras palavras, por marinheiros ibéricos" (Gunn, 1999, p. 61). Importa que o primeiro desembarque em Timor não foi alvo de um grande relato da literatura de viagens, tal qual a "certidão de nascimento" do Brasil, atribuída à Carta de Pelo Vaz de Caminha pela historiografia nacionalista brasileira (Novais, 2005). Assim, a chegada portuguesa na ilha não foi anunciada, à época, nos termos grandiloquentes da "conquista", tampouco do "achamento" (Gunn, 1999, p. 61). 
Mary Louise Pratt, em seu livro sobre relatos de viagem, argumentou que o "descobrimento" de certos lugares quase sempre envolvia

[...] alcançar aquela região e perguntar aos habitantes locais se eles sabiam de algum grande lago - ou o que quer que se estivesse procurando - na área, e, então, contratá-lo para que o levassem até lá, a partir do que, com sua direção e apoio, proceder-se-ia à descoberta do que eles já conheciam. (Pratt, 1999, p. 341)

Algo semelhante ocorreu em Timor, pois a ilha era conhecida e já se encontrava muito bem integrada em redes de troca regionais antes do advento europeu. Foi a conquista de Malaca, em 1511, que permitiu aos mercadores portugueses terem acesso às rotas de navegação para as "ilhas das especiarias" (Pinto, 2006). Como comprovam escritos não europeus, navegantes chineses, javaneses e árabes, também mercadores guzerates e macaçares, trafegavam intensamente, antes do século XVI, nas pequenas ilhas situadas a leste de Bali, região que era designada pelas culturas viajantes asiáticas como Timur, palavra que em malaio significa "leste" ou "oriente".

Seja como for, as comemorações de "500 anos" de Timor-Leste foram performadas como um ritual de origem e nascimento. Com ampla divulgação nacional e internacional, as celebrações foram nomeadas de maneiras diversas, destacando a "chegada dos portugueses", o "início da evangelização" e o "encontro de civilizações". Tais definições excluíam outras histórias de interações vividas em Timor, sobretudo, as mais longevas relações asiáticas com a ilha que não foram objeto de interesse e lembrança. Assim, escolha da data do evento emudeceu a longa história das trocas regionais, obliterando não apenas os saberes presentes nas literaturas asiáticas, mas suprimindo a própria reflexividade histórica destas, atreladas aos sistemas orientais de notação temporal, como o islâmico, o hindu e, principalmente, o chinês, considerado o mais antigo e que em 2015 registrava o avançado ano de 4713. A assunção do calendário gregoriano, como princípio classificatório do início do tempo histórico a ser relembrado em Timor-Leste, expressava assim o imperativo cristão e eurocêntrico implícito nas próprias categorias do pensamento que estruturaram as celebrações organizadas pelo Estado. 
A produção do evento envolveu a criação de uma Comissão da Organização das Comemorações dos 500 anos da Afirmação da Nova Identidade Timorense. Seu presidente em exercício, Dionísio Babo Soares, antropólogo e Ministro da Administração Estatal da República Democrática de TimorLeste (RDTL), tinha como função "preparar os eventos comemorativos, tendo em conta uma abordagem histórica, cultural e intelectual", que buscava "assinalar a chegada dos navegadores e missionários portugueses a Lifau" (Comemorações 500 anos, 2015). Assim escreveu no site da referida Comissão:

A longa caminhada histórica de Timor-Leste na construção da sua identidade nacional, marcada pelo primeiro contacto dos Portugueses a Lifau - Oecusse, há precisamente 500 anos atrás, espelha a unidade e coesão nacionais conquistadas com muita determinação, sacríficios, luta e vontade de mudança. [...] Ao longo destes 500 anos, mais precisamente desde 1976 até aos dias de hoje, registou-se a busca de uma nova identidade nacional que permitisse situar Timor-Leste no espaço político, geográfico, económico e social a que, por direito próprio, pertencia. (Comemorações 500 anos, 2015)

Ao evocar "500 anos", o presidente da Comissão reconhecia a importância da década de 1970 como um momento crítico na história do país. De fato, até a Revolução dos Cravos, em 1974, o "Timor Português" era a mais isolada e menos conhecida província ultramarina. Após uma breve, mas traumatizante, guerra civil, a Frente Revolucionária Timor Leste Independente (FRETILIN), partido político vitorioso, proclamou a independência. Dez dias depois, em 7 de dezembro de 1975, as forças armadas da Indonésia tomaram a capital. Renomeado como Timor Timur, o território foi transformado na $27^{\mathrm{a}}$ província da Indonésia e, durante 24 anos, viveu sob terror, levando a morte de quase um terço da população (Chomsky, 1999). A língua portuguesa, que nos últimos anos do colonialismo português era acessível a menos de $10 \%$ da população (Thomaz, 2002), foi proibida e o aprendizado do bahasa indonesia tornouse obrigatório mediante um aparato escolar que se ampliou rapidamente. A ocupação acelerou o desenvolvimento da consciência nacional timorense criando formas inéditas de resistência e solidariedade. Nesse contexto, a língua portuguesa chegou a transformar-se numa "arma 
dos fracos". Como indonésios a desconheciam, seu uso possibilitava a comunicação secreta entre os líderes da resistência que haviam sido escolarizados no período colonial (Lutz, 1995).

Assim, o presidente da Comissão vinculava em seu discurso a formação da identidade nacional timorense, gestada, sobretudo, no último quartel do século XX, com o momento mítico de contato dos portugueses, ocorrido cinco séculos antes. E foi deste modo que o quinto centenário foi abordado formalmente pelo Estado: em termos identitários. Os materiais oficiais produzidos pelo governo falavam em "afirmação", "reafirmação" ou mesmo "afirmação da nova identidade timorense", tal como anunciado no próprio título da Comissão. Provavelmente esta não clareza sobre o caráter fundador ou refundador da identidade afirmada seja um reflexo das próprias críticas que o evento sofreu.

Chama a atenção que a definição oficial das comemorações contrapunha-se à historiografia nacionalista timorense, surgida nos anos setenta e oitenta, escrita por intelectuais envolvidos na resistência à ocupação indonésia, como Abílio Aráujo (1977), José Ramos-Horta (1987) e Xanana Gusmão (1994). Estes, imaginaram a nação por meio do conceito maubere, um termo originário da língua mambae, significando "meu irmão", que se transformou num símbolo político e também num modo de enfatizar o caráter popular, nativista e tradicional da identidade timorense. Nessa tradição historiográfica, o acento anticolonial era forte e a história do país era narrada por meio das guerras e das lutas de resistência ao estrangeiro e não em função da aliança com estes (Leach, 2006). Essa é uma posição compartilhada por Abílio Araújo, intelectual timorense que não foi convidado a integrar a organização dos "500 anos":

Esta história que está sendo contada me parece um equívoco, a identidade timorense precede a presença portuguesa. Já sabíamos muito bem quem éramos antes dos europeus para cá virem. O governo de um país deveria perceber, ter visão mais larga, para não transmitir equívocos às gerações futuras³. (Araújo, 2015)

Outras críticas também foram expressas em função do evento, quase sempre em língua tétum. Como aquelas lançadas pelo periódico 
Suara Timor Lorosa'e que declarou que o governo celebrava o "dia da exploração", o "início da escravidão" e que para o povo o evento não trazia "vantagem". O periódico também questionava o "custo excessivo" das comemorações num país que é considerado um dos mais pobres da Ásia. De fato, no mês de abril de 2015, o então primeiro ministro anunciou que seriam alocados um milhão e meio de dólares unicamente para a organização dos "500 anos". A justificativa do montante foi de que "[...] a presença de convidados internacionais poderia contribuir para a dinamização e o crescimento da região" (Suara-Timor-Lorosae, 2015).

Uma programação das atividades foi apresentada no site Timor 500 - da chegada das caravelas. Constam ali seminários, debates e exposições temáticas sobre os "descobrimentos", "o catolicismo na Ásia" e "as relações entre Timor-Leste e Portugal". Mencionava também apresentações de filmes, concertos musicais, danças tradicionais, espetáculos de marionetes, lançamento de livros, exposições de fotografias, além de caminhadas coletivas, provas de motocicleta e corrida a cavalo (Timor 500 anos, 2015). Uma feira do livro, Mares de Palavras, que expunha para a venda e apreciação obras escritas em sua maioria em português, foi organizada pelo Instituto Camões. A programação oficial também incluiu atividades religiosas, como missas, celebrações de casamento, batismo e crisma.

Com recurso público e ampla divulgação, as atividades especiais dos "500 anos" foram sistematicamente integradas aos principais feriados relacionados ao processo de independência do país. O calendário nacional era então articulado em função da efeméride e as lembranças, emoções e os sentidos vinculados à recente história de libertação eram conectados às comemorações. O Estado produzia, assim, princípios de ordenação que sincronizavam a imaginação nacional de um tempo histórico curto, o da luta pela autodeterminação, com outro mais longo, o do advento europeu na ilha. Tornava-se, então, muito difícil aos cidadãos timorenses ignorarem esta associação temporal e esquecerem que no aniversário da proclamação da independência se comemoraria os "500 anos" da nação. 


\section{Nas Praias de Lifau}

A definição da data do evento acompanhou a determinação de um lugar-chave para as cerimônias. As comemorações se concentraram no distrito de Oecusse, exclave de soberania leste-timorense localizado na parte oeste da ilha e rodeado pela província indonésia de Nusa Tengara Timur (NTT) ${ }^{4}$. Hoje, presume-se que a região foi o lugar em que os portugueses primeiro se estabeleceram na ilha ${ }^{5}$, nas praias de Lifau, um pequeno monumento reforça essa narrativa. Em frente ao mar de Savu, uma coluna feita de pedras suporta um brazão português com uma cruz acima. Uma placa de pedra traz a inscrição "aqui desembarcaram portugueses em 18 de agosto de 1515". E no piso que circunda a coluna pode-se ler a afirmação "aqui também é Portugal". Os habitantes de Oecusse contam que aquele artefato não fora construído por portugueses, mas pelos próprios timorenses durante a invasão indonésia. Tal qual me foi explicado, quando visitei Oecusse em 2012, no período da ocupação a afirmação do vínculo com a antiga potência colonial significava também uma recusa ao novo ocupante, de modo que a construção do monumento era expressão de uma das formas da resistência praticadas no exclave ${ }^{6}$.

Transformada em uma zona estratégica de mercado, Oecusse hoje tem recebido grandes investimentos públicos para a edificação de infraestruturas, como estradas, um novo porto e aeroporto internacional. O projeto também favorece o próprio investimento privado que tem aquecido o mercado local com a maior presença de pequenos empresários timorenses e portugueses, além do capital chinês. Desse modo, o sentido das comemorações, ao dar visibilidade nacional e internacional a Oecusse, foi somado ao plano do Estado em transformar o exclave num dinâmico polo econômico e turístico. Como afirmou Mari Alkatiri, presidente da Região Administrativa Especial de Oecusse (RAEO): "a escolha de Oecusse é um pouco como voltar à história", "assim como Timor-Leste começou em Oecusse, o desenvolvimento de Timor-Leste vai começar em Oecussi para se estender ao resto do país" (Saponotícias, 2014). O objetivo da celebração era então ampliado, de modo que lembrar-se do passado associava-se ao projeto de vender a imagem daquele lugar no presente. 
Devido à dificuldade de acesso ao exclave, foram estabelecidas negociações com a Indonésia no sentido de facilitar o trânsito de funcionários e convidados pelas fronteiras. Inclusive a Comissão da Organização anunciou a participação indonésia nas atividades, com a realização de jogos entre as populações da zona fronteiriça, a apresentação de performances musicais de kerocong ${ }^{7}$ e também intercâmbio de experiências entre as comunidades católicas indonésias de Flores, Larantuka e Maluku, situadas nas ilhas próximas a Timor. A antiga potência ocupante fora então integrada ao evento, mas apenas na medida em que contribuía para os interesses deste: na facilitação das fronteiras, na valorização da herança cultural portuguesa no arquipélago e no reforço dos laços católicos com as ilhas da região.

Na praia de Lifau, um grande palco foi montado especialmente para apresentações artísticas e musicais, entre elas a performance do português Tony Carreiras e do cabo-verdiano Tito Paris. Mas o ponto alto foi a noite do dia 27 de novembro, quando seria inaugurado um novo monumento em homenagem aos "500 anos". O presidente são-tomense, o primeiro-ministro cabo-verdiano e o príncipe do Mônaco confirmaram presença na cerimônia. Mas na impossibilidade do presidente português, Cavaco Silva, ir a Timor-Leste, o Presidente do Tribunal Constitucional representou o Estado português. Com ele esteve também Dom Duarte Pio de Bragança, principal pretendente ao trono português e que ofereceu apoio à independência do país durante o período da ocupação indonésia. Frente às autoridades nacionais e internacionais, o então presidente da RDTL, Taur Matan Ruak, pronunciou:

O mar é a realidade física e geográfica que permitiu nosso encontro entre timorenses e portugueses, asiáticos e europeus. Este encontro foi importante porque representou a abertura de Timor ao mundo exterior. Abertura ao mundo que começou em Lifau e nunca mais parou [...] a língua portuguesa foi a língua da resistência pois foi a língua que os combatentes compreendiam mas nossos adversários não. (Timor 500 anos, 2015)

Já no discurso do jantar oferecido após a inauguração do monumento, o então primeiro ministro, Rui Maria de Araújo, mais 
uma vez reforçou a narrativa da aventura marítima e a importância da língua portuguesa:

Remonta ao princípio do século XV, após a conquista de Ceuta, o início da expansão marítima portuguesa que promoveu sucessivas descobertas no grande continente africano, permitindo a Vasco da Gama percorrer a sua rota até alcançar as Índias e a Pedro Álvares Cabral, na procura do comércio com o oriente, desviar-se da sua rota para encontrar o Brasil. Continuando a odisseia marítima e atraídos pela riqueza do oriente, a tomada de Malaca possibilitou uma profunda presença portuguesa nesta região, potenciando toda uma nova lógica empreendedora, estreitando relações comerciais com a Ásia Oriental e chegando a Solor e Flores, e, mais tarde, atraídos pelo nosso valioso sândalo, a Timor. Os portugueses e os missionários trouxeram e deixaram, de vários cantos do mundo, muitos traços linguísticos e históricos, conhecimentos, valores e sentimentos que se foram enraizando e permanecem até hoje na nossa cultura, moldaram e influenciaram a nossa formação e a nossa educação e constituem um património único de Timor-Leste. A coabitação destes traços trazidos pelos portugueses veio enriquecer ainda mais a identidade autóctone timorense, o que faz de nós um povo com características únicas na região. [...] Hoje somos nós os navegadores de Timor-Leste e, tal como os navegadores que chegaram na caravela que hoje acabámos de inaugurar, somos nós, timorenses, "os homens do leme"! (Primeiro Ministro, 2015)

Os discursos dos chefes de Estado e de governo de Timor-Leste referiam-se com orgulho à chegada dos navegadores portugueses, como principais agentes da gestação da nação: trouxeram a língua, estabeleceram a cruz, colocaram Timor no mapa colonial e na história d'Os Lusíadas. Assim o apresentaram ao mundo exterior. Essas performances do poder nacional incorporavam o próprio discurso imperial dos "descobrimentos", sugerindo que antes do advento europeu os ilhéus estariam fechados num mundo interior, desprovidos deste bem maior que é o evangelho e destituídos de uma língua que os permitiu resistir contra a ocupação estrangeira. A longa e penosa viagem marítima teria levado, assim, a um necessário enriquecimento cultural dos 
"autóctones". As duas evocações do encontro colonial, destacaram, sobretudo, uma interação unidirecional, portugueses contribuíram para a formação da nacionalidade timorense, mas o movimento reverso sequer foi interrogado.

Importa que tais discursos não foram apenas verbalizados pelas figuras de proeminência política. Seus sentidos também estavam inscritos no monumento recém-inaugurado, um forte argumento visual e material, confeccionado especialmente para ocasião e que foi consagrado no coração do ritual.

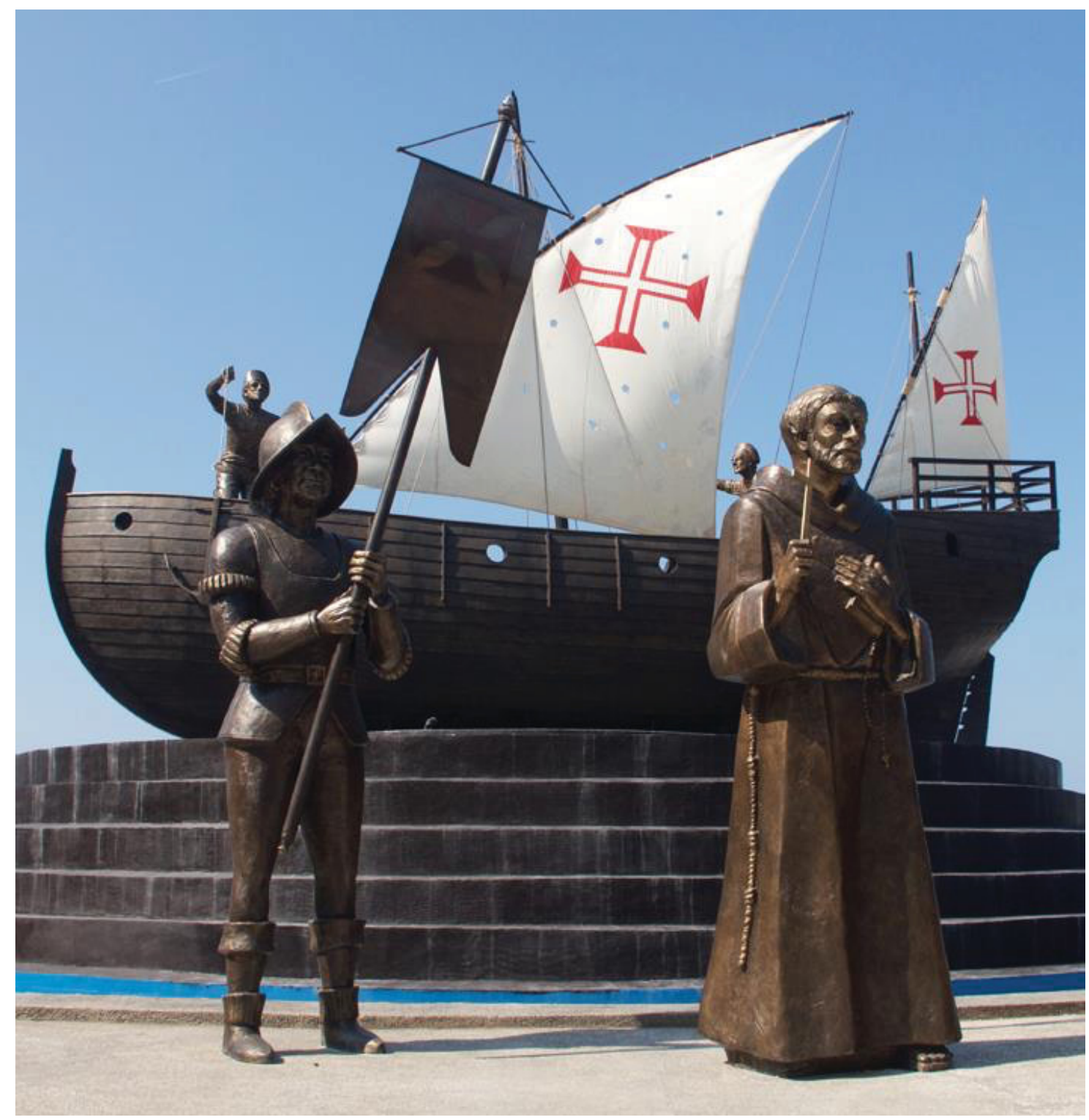

Figura 2: Detalhe do novo monumento de Lifau. Padre catequista e porta estandarte em primeiro plano. Ao fundo, caravela com dois marinheiros Fonte: Observatório da Língua Portuguesa (2015) 
Pesando oito toneladas e medindo 4,3 metros de altura e 3,2 metros de largura, o novo monumento de Lifau é composto de uma caravela e oito figuras feitas em bronze de lei. O conjunto global da cena apresenta dois marinheiros menores que se encontram no interior da embarcação, três timorenses que recebem os recém-chegados e, saindo da embarcação, três figuras europeias que se voltam aos ilhéus. As figuras não possuem nomes. Mas diferentemente dos marinheiros e dos timorenses, sem maiores caracteres distintivos, os europeus em solo possuem um maior detalhamento na indumentária. Joaquim de Brito, português e projetista do monumento, afirmou em entrevista que os três portugueses representariam, respectivamente, um "portaestandarte", um "padre catequista" e um "descobridor". E segundo o designer, a obra encenaria "o grande encontro entre os dois povos" (Um Livro, um amigo para Timor, 2016).

Feito em Portugal e de lá vindo, o grande artefato carrega consigo visões, valores e uma narrativa própria, forjando um simulacro da cena imperial dos descobrimentos que não é assim nomeada. Na placa de identificação pode-se ler: "Interação Cultural 1515-2015". Mais uma vez temos aí uma legenda oficial das celebrações que silencia conceitos e visões implícitas em nome de um multiculturalismo anunciado. A estatuária do monumento não só exclui a presença de mulheres, crianças, animais e vegetais (o sândalo), representando uma história feita unicamente por homens, mas também subalterniza e simplifica o papel central de outros agentes fulcrais à feitura do império marítimo português no Oriente, como os trabalhadores do mar e as autoridades locais. Os primeiros, como se sabe, não eram exatamente "portugueses", mas compostos por muitos asiáticos e mercadores mestiços - lusoasiáticos chamados de "casados" (Subrahmanyam, 2012) - que conheciam as línguas do arquipélago, também seus mares e ventos, e eram capazes de adaptar as embarcações portuguesas com tecnologias e materiais locais. Isso quando as viagens à Insulíndia não eram, elas mesmas, efetuadas em barcos de junco, naus maiores e melhores adaptadas, aos bancos de areia, que as pequenas e desajeitadas caravelas ibéricas de casto fundo (Pinto, 2014). Por outro lado, a caracterização exótica dos ilhéus seminus na estatuária, portando espadas, crinas e 
acessórios que ainda hoje são reconhecidos como índices da "tradição" no país, contrasta com os "fetiches" da civilização européia trazidos pelos corpos vestidos dos recém-chegados: a escrita, a cruz e o brazão. É uma cena romantizada que se quer originária e fundadora. E para isso exalta a pureza e o protagonismo de figuras icônicas como o carregador da bandeira portuguesa, o missionário e, o mais anacrônico de todos, o "descobridor" - como se esta fosse uma função ou um cargo fixo nas embarcações ibéricas dos quinhentos.

Mais que tudo, a narrativa proposta pela performance monumental em bronze oblitera o lugar do desentendimento, da assimetria e da violência, características essas constitutivas das zonas de contato (Pratt, 1999). Trata-se de uma cena idílica que promove a trivialização a história (Trouillot, 1995). Sobretudo se considerarmos a hostilidade constitutiva dos circuitos de mercado de especiarias na insulíndia do século XVI e que, no caso específico de Timor, o mais antigo documento português a descrever a interação com os ilhéus sugere o uso da força na coleta do sândalo. Como diz uma carta de 1516 relatando uma viagem de Malaca (apud Gunn, 1999, p. 61) a Timor: "[...] deixaram uma terra em tumulto, dado que os portugueses espancaram mercadores da terra".

O novo monumento integra parte de um projeto arquitetônico mais amplo, intitulado "Complexo Museológico de Lifau" e que ainda permanece no papel. Mas a produção do artefato já estabelecido parece ter sido alvo de algum debate e ingerência por parte de autoridades do Estado timorense, instituição financiadora da obra. Mari Alkatiri, presidente da Região Administrativa Especial de Oecusse (RAEO), relatou que "no desenho original da caravela estava escrito 'Vasco da Gama'. Era uma coisa dos portugueses que não podíamos deixar passar. Vasco da Gama nunca pisou em Timor" ${ }^{\prime \prime}$. Mesmo com alterações, o resultado final parece não ter agradado a todos. Quando estive em Timor, em 2015, uma funcionária da RAEO contou-me que a representação dos timorenses no monumento incomodou alguns moradores de Oecusse. Segundo ela, a estatuária apresentava nativos com indumentária tradicional característica da ponta leste da ilha e não do exclave de Oecusse. Aqueles que viviam na parte oeste da ilha e que tinham o baiqueno como língua materna, alegavam assim, não tanto uma interpretação incorreta do primeiro contato, mas a própria 
dificuldade em se identificarem com os personagens que ali deviam representá-los.

\section{Entre a Cruz e a Espada}

Além da participação de inúmeras entidades do Estado timorense, a organização dos "500 anos" contou com o apoio de instituições portuguesas atuantes no território, como a Fundação Mário Soares, o Instituto Camões, a Fundação Oriente e a própria embaixada de Portugal. Para a comunicação e publicidade do evento, o governo da RDTL confeccionou um logo. Já outro logo foi feito pela Fundação Mário Soares. Até onde pude saber, não houve concorrência entre as imagens. A primeira foi divulgada nos órgãos do Estado timorense. A segunda circulou nos espaços com maior presença da cooperação internacional portuguesa e também serviu como capa do catálogo preparado para exposição. Em todo caso, ambas as imagens tiveram difusão restrita, concentrada, sobretudo, em Díli e Oecusse, além da própria internet. Suas diferenças, no entanto, me parecem instrutivas sobre o modo como duas formas da imaginação nacional podem projetar, sintetizar e visualizar os "500 anos" de Timor-Leste.

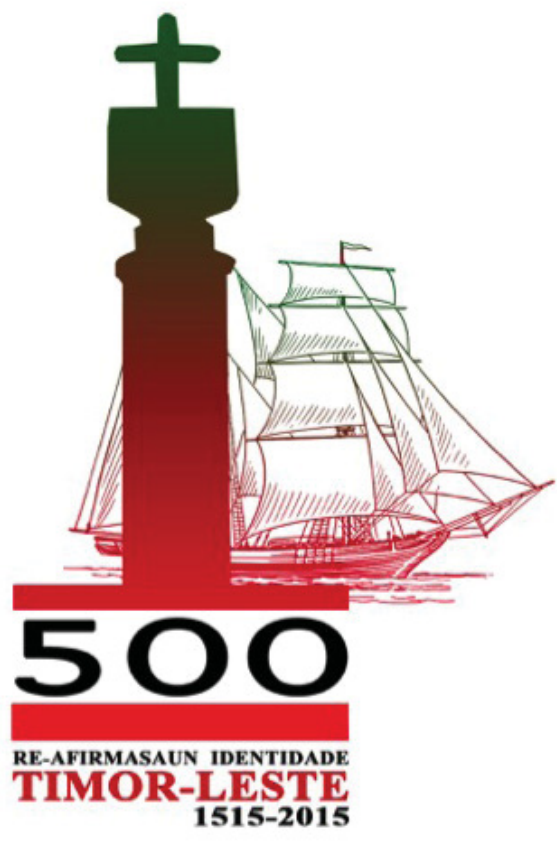

Figura 3 - Logo feito pelo governo Fonte: Comemorações 500 anos (2015)

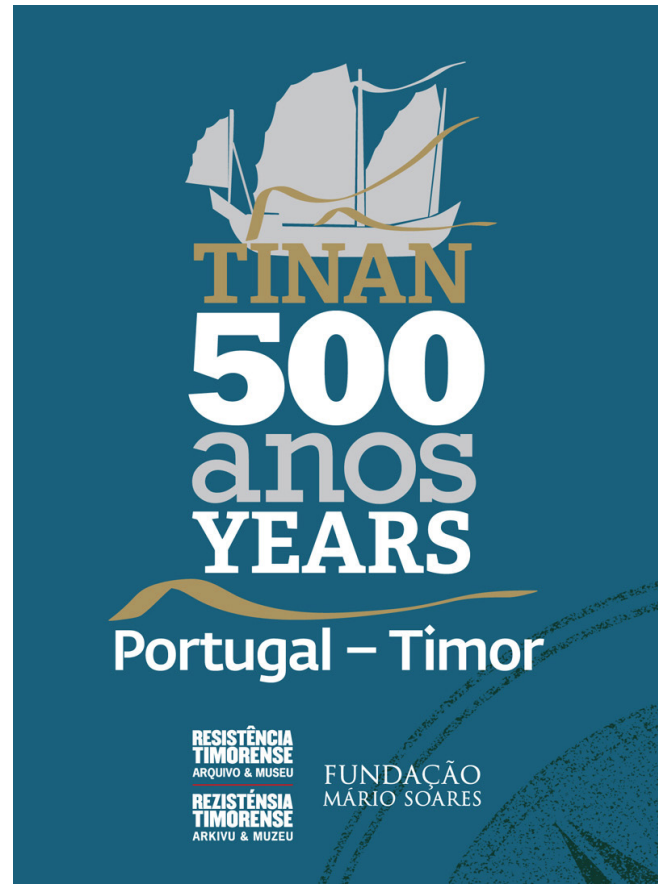

Figura 4: Logo feito pela cooperação portuguesa Fonte: Mary Martins Broksellers (2015) 
Em uma aproximação imediata, ambos logos exibem aspectos comuns. Destacam o numeral "500", apresentam palavras em tétumpraça e expõem a imagem de uma embarcação que traz consigo a narrativa das navegações. Mas as dessemelhanças entre os documentos visuais sugerem pontos interessantes. De fundo branco, a imagem oficial do governo, à esquerda, apresenta em primeiro plano o sustentáculo da Cruz. Abaixo da coluna é que surgem números e palavras descrevendo o evento: 500 re-afirmasaun identidade Timor-Leste 1515-2015. A embarcação encontra-se apenas atrás do pilar, no desenho avermelhado de um veleiro cujos traços não parecem ser exatamente aqueles das caravelas ibéricas quinhentistas.

Por sua vez, a logo criado pela Fundação Mario Soares, em parceria com o Arquivo \& Museu da Resistência Timorense (AMRT), destaca a figura de um barco acima de tudo. Abaixo seguem outras informações inscritas: tinan 500 anos years Portugal-Timor. A palavra em tétum é conectada às traduções em português e inglês, impulsionando o evento para o marco transnacional e plurilíngue. Aqui a referência a Timor é antecedida por Portugal, sugerindo precedência do último. Chama a atenção que o desenho da embarcação representada possui elementos orientais, o que é visível pelo formato das velas que se assemelham das naus de junco características do mundo marítimo sul asiático. A cor de fundo da imagem é azul escuro com tons de verde e, abaixo à direita, nota-se uma marca d'água com traços que remetem à bússola ou rosa dos ventos, cores e instrumentos de orientação que são índices da vida no mar. Os dois logos apresentam artefatos marítimos e insinuam, assim, que os "500 anos de Timor-Leste" só foram possíveis, pois, à época, existiam embarcações que permitiram "grandes navegações". Talvez a diferença mais evidente seja que enquanto no segundo logo a caravela e o vínculo com Portugal é explícito, sugerindo primazia sobre outros elementos, no primeiro, a cruz é a principal marca, instaurando ordem e simetria à imagem, e colocando-se como ícone preponderante e de fundamento na proposta visual. No logo confeccionado pelo governo timorense, a sugestão maior que fica é de que Timor-Leste só foi possível graças ao advento da cruz. Ali, a omissão do nome de Portugal dá espaço à presença de um símbolo religioso que secundariza o lugar da embarcação. 
De fato, "o início da evangelização" foi o motivo de maior sensibilização popular para a celebração dos "500 anos", muito mais impactante, por exemplo, que a alegada "chegada dos portugueses". Isso não por acaso, já que a história recente da igreja no país é central para a compreensão do nacionalismo timorense. No Timor colonial de 1952 os católicos constituíam 13\% da população, em 1973 alcançavam 29\% (Carey, 1999, p. 79). Com a ocupação indonésia a adesão ao catolicismo aumentou, chegando a 90\% como resultado das "conversões em massa" (Legaspi, 2012). A doutrina pancasilla, ideologia oficial da República Indonésia, exigia a filiação a uma das cinco religiões do livro: islamismo, catolicismo, protestantismo, hinduísmo ou budismo. Além disso, a Orde $\mathrm{Baru}^{9}$ era marcadamente anticomunista fazendo com que todos aqueles classificados como "sem religião" pudessem ser identificados como inimigos do Estado. Assim, timorenses aderiram à religião que possuíam maior proximidade, fazendo com que o maior aumento do número de católicos na ilha ocorresse na ocupação indonésia e não na colonização portuguesa. E isso, num ambiente fortemente marcado pelo islamismo da potência ocupante, país com a maior população de muçulmanos no mundo. Mas em Timor ocupado, a oposição ao islamismo somouse a rejeição do próprio catolicismo indonésio. A Diocese de Díli, recusando-se a subordinar-se à hierarquia eclesiástica de Jakarta, passou a responder exclusivamente ao Vaticano, adquirindo maior liberdade e ares de "igreja nacional". Com a proibição do português, a expectativa indonésia era de que a Igreja católica incorporasse o bahasa indonesia em suas missas. Mas a Santa Sé autorizou a utilização do tétum-praça, o que aproximou ainda mais a igreja das comunidades rurais e estimulou a difusão do tétum-praça como língua franca no território. Formou-se, assim, um catolicismo popular tetumófono que, segundo Anderson (1994), não seguiu aquele modelo de nacionalismo derivado exclusivamente da articulação entre imprensa e capitalismo.

Mesmo após a restauração da independência, em 2002, a igreja católica continuou se colocando como a representante legítima do povo, sendo que em momentos de crise chegou a assumir o lugar de porta-voz da nação no enfrentamento direto com o Estado (Silva, 2007). Segundo o censo de 2010, 96,9\% da população de Timor-Leste é católica, 
colocando-o como país de maior proporção dessa religião na Ásia. E se o "início da missionação" foi o significado menos contestado das comemorações dos "500 anos", também foi aquele que mais promoveu a aderência das massas. Cerimoniais religiosos e missas especiais foram efetuadas. E nestes momentos atrelava-se a alegada presença de meio milênio da igreja na ilha com seu importante papel na acolhida do sofrimento do povo. Mais uma vez, o evento era ritualizado como forma de conectar um tempo de longuíssima duração ao breve tempo histórico de formação da nação e difusão do catolicismo.

Um ano antes das comemorações, em março de 2014, o presidente da Conferência Episcopal de Timor-Leste e também Bispo de Baucau, Dom Basílio do Nascimento, juntamente com outros dois Bispos, foram à Santa Sé. Em um encontro pessoal com o Papa Francisco, os sacerdotes timorenses convidaram o pontífice para as celebrações dos "500 anos". Com uma viagem programada para a Ásia, a expectativa era de que ele pudesse participar do evento. Se somada à breve e conturbada visita do Papa João Paulo II, ocorrida em 1989, num evento que colaborou para a virada da opinião pública internacional a respeito da ocupação indonésia, esta seria a segunda vinda de um Santo Padre ao território.

A viagem do pontífice pela Ásia ocorreu em janeiro de 2015. Ele passou pelo Sri Lanka, onde canonizou o primeiro santo daquele país de minoria católica, e fomentou o diálogo inter-religioso, considerando o longo conflito civil entre tâmil e cingaleses. Também visitou as Filipinas, o maior país asiático de maioria católica, buscando confortar os atingidos pelo Tufão Yolanda. Timor-Leste acabou por ficar fora do circuito papal, mas a Santa Sé deu sinais de apoio e reconhecimento. O Cardeal Pietro Parolin, representante diplomático e Secretário de Estado do Vaticano, foi enviado com dois objetivos principais: promover uma concordata e participar da festa de Assunção de Nossa Senhora em Timor-Leste que, naquele ano, foi dedicada exclusivamente aos "500 anos da evangelização". O acordo diplomático buscava estreitar a cooperação entre o Vaticano e a RDTL, reforçando um claro entendimento da separação entre Estado e igreja. Por sua vez, a missa solene, presidida pelo próprio delegado do pontífice, adensou boa parte dos sentidos católicos dos "500 anos" e ocorreu no dia 15 de agosto, 
em Taci Tolu, Díli, no mesmo lugar visitado pelo Papa João Paulo II em 1989. Perante uma multidão de centenas de pessoas, com a presença de vários bispos timorenses, também sacerdotes católicos oriundos da Austrália, Singapura e Indonésia, além do presidente e do primeiro ministro de Timor-Leste, o Cardeal leu uma carta enviada pelo Papa Francisco. A mensagem assinalava o reconhecimento da efeméride, a "coragem" e as "incontáveis dificuldades" que os "empreendedores missionários" tiveram ao levar o evangelho à região de Timor ${ }^{10}$ (Rádio Vaticano, 2015).

Mas se as celebrações católicas foram concentradas em agosto na parte leste da ilha, na parte oeste, a dimensão religiosa não foi excluída das comemorações oficiais. No mês de novembro, o maior movimento de massas em Timor-Leste contemporâneo, a Cruz Joven, após uma grande peregrinação por paróquias de todo território timorense, chegou ao exclave de Oecusse. Uma colega que esteve presente nas comemorações de Lifau me relatou que vários membros da Cruz Joven chegavam à praia utilizando uma mesma camiseta preta. Nesta podia-se ler a frase estampada: "esta terra não foi conquistada pela espada, mas pela água e pelo sal". Esse argumento, repetido com certa frequência no país, constitui uma afirmação que exclui a selvageria da hostilidade colonial em privilégio de uma narrativa de pureza atribuída à evangelização. Trata-se, pois, de uma afirmação que silencia inúmeras experiências nas quais a espada esteve umbilicalmente associada à cruz: o negócio dos padres comerciantes de sândalos e escravos na região de FloresTimor, no fim do século XVI (Gunn, 1999, p. 66); o papel das missões católicas nas guerras contra o "paganismo" e o "barbarismo" na ilha, bem como a preparação e o envio de cabeças decapitadas para os estudos de antropologia física na metrópole (Roque, 2010); ou mesmo no início do século $\mathrm{XX}$, a destruição, o saque e a perseguição às casas sagradas timorenses, "[...] um dos principais pontos de mira da atuação missionária, se não o principal" (Rosa, 2012, p. 18). No entanto, não foram estas as experiências lembradas nas cerimônias dos "500 anos de evangelização". Disso esqueceu-se ou não se falou. Ali, o que foi produzido como história é que a conquista de Timor, seu ritual de nascimento e purificação, não se fez pelo estrondoso golpe da lâmina, mas pelo imaculado ato do batismo. 


\section{Geopolítica dos 500 Anos}

As celebrações centenárias do advento europeu constituem um campo profícuo para análise comparativa e internacional, pois possuem significados e implicações distintas a depender da posição regional dos Estados-nação, suas histórias coloniais e pós-coloniais, bem como o tratamento governamental diferenciado ofertado a suas populações. É nesse sentido que o "espaço lusófono" somente pode ser abordado de forma crítica, considerando suas descontinuidades e assimetrias. Em 2000, as comemorações dos "500 anos de descobrimento do Brasil" não só incitaram a resistência dos movimentos sem-terra, negro e indígena, mas também deixaram perplexos os observadores internacionais. Estes se perguntaram se os brasileiros não tomaram conhecimento dos debates de 1992, quando vozes de todo o mundo atacaram o vocábulo dos "descobrimentos" e impediram que o heroísmo de Colombo nas Américas fosse cantado nos mesmos termos que o foram nas celebrações dos "400 anos" em 1892 (Carvalho, 2003). As celebrações dos "500 anos do descobrimento da América" praticamente não tiveram impacto no Brasil, que se manteve distante das festividades continentais (Monteiro; Thomaz, 1996). O gigante sul americano preferiu comemorar seu quinto centenário de forma separada e exclusiva, oito anos depois, numa festa em que os países vizinhos não foram convidados e que a ex-metrópole foi V.I.P. Aqui, a grande narrativa euro-americana dos "descobrimentos" assumiu uma modulação própria, segregando Colombo e exaltando Cabral como ícone brasileiro do pós-colonialismo em português.

Tal como no Brasil, a chegada dos portugueses na ilha de Timor foi abordada como fundadora da nação, inaugurando a cronologia de um novo tempo. Em ambas as celebrações, as técnicas de encenação do passado produziram uma trivialização dos eventos históricos, na medida em que não foram disponibilizados ao grande público elementos para elaborar uma visão crítica das relações de poder que permearam o contexto retratado. Também nos dois "500 anos" certos tópicos comuns apresentaram redundância temática: a identidade nacional, o vínculo com Portugal e a igreja católica (Silva, 2003). Se é certo que no Brasil o ano de 1900 fora marcado por uma primeira celebração centenária do "descobrimento"11, em Timor-Leste isso nunca ocorrera antes. Não 
havendo uma tradição nacional da ritualização do "encontro colonial", os sentidos históricos, geográficos e culturais do evento tiveram de ser inventados a partir dos materiais e interesses existentes.

Em Timor-Leste não se falou em "descobrimento". Ainda que esta última palavra não tenha sido oficialmente utilizada, muito da lógica que lhe subjaz se fez presente. "Colonização" foi outro termo evitado em Timor-Leste, sendo pronunciado apenas como uma forma de exaltação de sua excepcionalidade. Tal como fez José Ramos-Horta, ex-presidente e ex-primeiro ministro do país, que em artigo amplamente difundido declarou: "facto inédito no mundo em que um povo colonizado toma a iniciativa em celebrar a chegada dos colonizadores nas suas praias e o início de séculos de colonização". O laureado prêmio Nobel da Paz não só esquecia da efeméride brasileira, ocorrida apenas quinze anos antes, mas parecia ter assumido um discurso presente naquela, afirmando uma "relação exemplar", "sem preconceitos nem complexos em relação a Portugal"( Sapo24, 2015). O cotejo das duas comemorações aponta, portanto, para aproximações no modo como as duas nações gerem seu passado colonial. Algo muito distinto dos Países Africanos de Língua Oficial Portuguesa (PALOP) que, fortemente marcados pela memória do racismo e da guerra colonial, concebem a celebração da "chegada dos portugueses" como algo completamente inimaginável. Diferentemente destes, as duas ex-colônias portuguesas situadas nas antípodas do globo colocaram-se cerimonialmente como parte do "mundo que o português criou", reforçando o ideal lusotropical (Castelo, 1999) de uma relação colonial afetiva e cordial, e fazendo com que tal relação fosse anunciada como parte de uma ética da casa, uma questão de parentesco. Assim diz a explicação que por diversas vezes escutei em Díli: “A CPLP (Comunidade dos Países de Língua Portuguesa) é uma grande família. Portugal é o nosso pai, Brasil o irmão mais velho e Timor-Leste o irmão mais novo".

Sendo os únicos países colonizados por Portugal e de língua oficial portuguesa nos diferentes contextos continentais em que estão inseridos, as celebrações promovidas pelo Estado brasileiro e timorense fortificaram as fronteiras da imaginação nacional em relação aos territórios vizinhos, exaltando o vínculo com o ex- 
colonizador em detrimento das relações regionais. Mas se no Brasil as contestações aos "500 anos", promovidas pelas classes subalternas, e a violência repressiva, promovida pelo Estado, evidenciaram lógicas de "colonialismo interno", em Timor-Leste, a ritualização política da história colonial também chegou a ser interpretada como impositiva e autoritária, ainda que não tenha produzido conflitos abertos. Sávio Ma'averu, ativista e historiador timorense, em texto reflexivo sobre o evento ritual criticou o argumento oficial do "cruzamento cultural" projetado para o contexto assimétrico do processo de "colonização". Segundo ele, ao exaltar o primazia lusitana na definição da identidade timorense, a celebração teria silenciado outro "cruzamento cultural" determinante na ilha: o "melanésio-austronésio" (Ma'averu, 2016). Também Mica Barreto-Soares, outra pesquisadora e ativista timorense, em artigo intitulado Komemorasaun Forsadu?, denunciou o caráter não democrático e não participativo do evento, acusando a "mentalidade colonialista do governo" como responsável por incitar "sentimentos xenófobos e racistas", na medida em que a exaltação unívoca da amizade com Portugal reforçou dissensos e não ditos, impedindo que se discutisse tópicos delicados, associados à mágoas da população em relação ao passado colonial e ao lugar da língua portuguesa hoje (Forum Haksesuk, 2015).

Em vários aspectos, os "500 anos" de Timor-Leste não fugiram à regra de outras celebrações centenárias do advento europeu, na medida em que divulgaram uma história espetacular marcada pela perspectiva das elites dirigentes. Tais comemorações, no entanto, não são comuns na Ásia do Sul e do Sudeste, região fortemente marcada pela resistência anticolonial e pela intolerância a qualquer forma de nostalgia colonial. Mas em Timor-Leste, o nacionalismo não se desenvolveu na luta contra o colonizador, tal qual o percurso de outras nações asiáticas, e sim no combate à ocupação neocolonial indonésia, mobilizando para isso a cultura do ex-colonizador como forma de contestar o invasor. É isso que permite compreender como, na noite de 27 de novembro de 2015 , o monumental artefato encenando a chegada dos colonizadores foi 
inaugurado para logo na manhã do dia seguinte, no aniversário de 40 anos da proclamação da independência, o hino nacional timorense ser entoado com os versos, do poeta e revolucionário Borja da Costa (2009), bradando "vencemos o colonialismo" e "abaixo o imperialismo".

Podendo ser interpretada como "colonialismo interno" em TimorLeste, a presença portuguesa, contextualizada em escala regional, afirma a diferença histórica de um país territorialmente diminuto e entalado entre dois gigantes: Indonésia e Austrália. Ao assumir o modelo ritual lusocêntrico dos "descobrimentos", Timor-Leste integra parte de uma história mais ampla, distinta daquela proposta pela narrativa nacionalista do antigo Estado invasor. No período da ocupação, o regime indonésio utilizou-se de documentos ancestrais, que atestavam a longeva influência do império javanês de Majapahit sobre a ilha de Timor, antes da chegada dos portugueses, com forma de legitimar a "anexação". Nessa história, a presença europeia era interpretada como uma interferência estrangeira temporária que seria corrigida com a (re) integração da parte leste da ilha à grande Indonésia - uma narrativa semelhante àquela adotada por Nehru, por ocasião da "reintegração de Goa" à União Indiana em 1961. Contudo, as celebrações dos "500 anos" de Timor-Leste reforçaram uma outra narrativa: a que afirma sua filiação à matriz cultural lusitana, com sua religião e língua. Nesta versão da história, a invasão indonésia é interpretada como uma interferência estrangeira temporária, impedindo o livre curso da "descolonização" do país.

Nos anos da ocupação, a resistência diplomática timorense obteve apoio de nações que, em 1996, integraram a Comunidade dos Países de Língua Portuguesa (CPLP), uma organização que teve como primeiro objetivo comum o apoio à independência de Timor-Leste. Em 2014, um ano antes das celebrações, Díli sediou a X Cimeira da CPLP, ambiente no qual tais eventos foram lembrados, assim como foram relembrados por ocasião das comemorações de 2015. Assim, diferentemente do Brasil, os "500 anos de Timor-Leste" deram especial atenção à língua portuguesa como emblema de identificação nacional e não se voltaram exclusivamente ao diálogo com a ex-metrópole, ampliando horizontes diplomáticos e reforçando alianças geopolíticas "lusófonas" capazes de 
projetar o país para além do contexto regional imediato que o apequena. Mais que tudo, as celebrações foram uma estratégia para legitimar uma tradição nacional com muito menos história que a brasileira. Insulado, com uma população cuja média de idade não alcança os 19 anos (Atlas Mundial de Dados, 2016) e conquistando a independência apenas no século XXI, Timor-Leste lida com representações que personificam a nação como "pequena", "jovem" e "recém-nascida". Com isso, a cópia dos modelos rituais euro-americanos e sua transferência para o contexto timorense também são uma forma do Estado-nação reivindicar, para os seus e para os outros, experiência, maturidade e meio milênio de tradição.

\section{Notas}

1 Permaneci dois anos no país. No primeiro como professor-visitante contratado pela Universidade Nacional Timor-Lorosa'e (UNTL) e no segundo como professor e "articulador pedagógico" da Cooperação Brasileira pelo programa PQLP-CAPES. Agradeço a essas duas instituições pelo suporte oferecido.

2 Recentemente a crítica ao racismo em Portugal parece ter gerado algum impacto nos significados atribuídos aos "descobrimentos" e ao "colonialismo". Ver por exemplo a recepção do projeto "racismo em português", organizado por Joana Gorjão e divulgado no Público: < https://acervo.publico.pt/racismo-em-portugues > . Acesso em: 18 jan. 2017.

3 Entrevista efetuada com Abílio Araújo em julho de 2015.

4 A definição territorial de Oecusse foi resultado de uma longa negociação sobre a fronteira colonial luso-holandesa da ilha, iniciada em meados do século XIX e concluída apenas no início do século XX (Pélisser, 1996). Grafada de modos distintos, como Oecússi ou Oe-kusi, a região é mais um "exclave" que propriamente um "enclave", pois possui uma saída para o Mar de Savu, ao norte, não estando completamente envolvida pelo território do Estado indonésio.

5 O primeiro estabelecimento de missionários dominicanos nas pequenas ilhas de Sonda ocorreu não em Timor, mas em Solor, na década de 1550 (Durand, 2001, p. 34). O primeiro governador português nomeado em Timor tomou lugar em Lifau apenas em 1702, sendo que em 1769 a praça teve de ser abandonada devido ao cerco dos chefes locais, forçando o deslocamento da presença portuguesa ao leste, na baía de Díli, capital que se manteve desde então (Gunn, 1999, p. 110).

6 Oecusse foi o primeiro território leste timorense a ser invadido pelo exército indonésio e, logo após sua desocupação (1999-2002), a viabilidade do exclave como parte integrante de Timor-Leste independente foi muito questionada, sobretudo por observadores internacionais. Como se notou depois, esta postura subestimava o forte nacionalismo leste-timorense existente em Oecusse, um sentimento atrelado à memória da dor e do trauma imposto pelo Estado vizinho (Crisis Group, 2010).

7 Também chamado de kroncong, o termo nomeia um estilo de música indonésio considerado tradicional no país, que envolve cantos e danças e é executado cole- 
tivamente em grupos ou orquestras. O principal instrumento do kerocong tem o mesmo nome, assemelha-se ao ukulele havaiano e, tal como este último, constitui uma apropriação local dos pequenos instrumentos ibéricos de cordas trazidos por viajantes portugueses aos arquipélagos.

8 Entrevista com Alkatiri feita em abril de 2014.

9 Orde Baru, "nova ordem" em português, diz respeito ao regime político iniciado com o golpe de Estado indonésio que colocou Suharto no poder, com o apoio das potências ocidentais, entre 1965 e 1998. Justificada internacionalmente como um "contragolpe comunista", a instauração da Orde Baru foi iniciada com o assassinato de cerca de 2 milhões de cidadãos indonésios "esquerdistas" e com o fim do PKI, à época, o maior partido comunista do mundo fora do bloco sino-soviético (Bertrand, 2001). O legado da Orde Baru revela-se também na língua, já que Suharto alterou drasticamente a ortografia do bahasa indonesia, dificultando a interpretação da documentação escrita pré-golpe, alargando a distância entre as novas e velhas gerações e contribuindo, junto com a censura instalada, para a formação de uma profunda "amnésia política" (Anderson, 2008).

10 Sobre a missa solene, ver a matéria neste link: < https://www.youtube.com/watch?v=5DrgY-gwGos $>$, acesso em 12 de outubro de 2016.

11 Diferentemente dos eventos de 2000, em 1900 a efeméride se desenrolou num contexto de tensão diplomática com Portugal, que havia rompido relações com o Brasil em 1893. A ex-metrópole interpretava a proximidade com a nova república sul-americana como uma real ameaça à crise monárquica que, por fim, chegaria a termo em 1910 (Oliveira, 2000).

\section{Referências}

ALMEIDA, Miguel Vale de. O epílogo do império: Timor-Leste e a catarse pós-colonial portuguesa. Novos Estudos CEBRAP, [S.l.], n. 55, novembro de 1999.

ATLAS MUNDIAL DE DADOS. Timor Leste - Idade Média do Total da população. [2016]. Disponível em: <http://pt.knoema.com/atlas/TimorLeste/topics/Demografia/Faixa-etária/Idade-média-da-população > . Acesso em: 12 jun. 2016.

. O Atlântico Pardo. Antropologia, pós-colonialismo e o caso "lusófono". In: BASTOS, C.; ALMEIDA, M. V.; FELDMAN-BIANCO, B. Trânsitos Coloniais: Diálogos críticos luso-brasileiros. Campinas, SP: Editora Unicamp, 2007. p. 27-43.

ANDERSON, Benedict, Comunidades Imaginadas: reflexões sobre a origem e a difusão do nacionalismo. São Paulo: Companhia das Letras, 2009.

. magining Timor-Leste". Arena Magazine, [S.l.], v. 4, 1994. Exit Suharto: obituary for a mediocre tyrant. New Left Review, [S.l.], v. 50, March-April, 2008. 
ARAÚJO, Abílio. Timor Leste, Os Loricos Voltaram a Cantar: das guerras de independentistas à revolução do povo maubere. Lisboa: edição do autor, 1977.

BERTRAND, Romain. Indonesia Raya: les trois âges du nationalisme indonésien. Timor: les défis de l'indépendence - Lusotopie, Paris: Éditions Karthala, v. 8, n. 1-2, 2001.

CAREY, Peter. The Catholic Church, Religious Revival, and the Nationalist Movement in East Timor, 1975-1998. Indonesia and the Malay World, [S.l.], v. 27, n 78, p. 77-95, 1999.

CARVALHO, José Murilo de. Nação imaginária: memória, mitos e heróis. In: NOVAES, Adauto (Org.), A crise do Estado-nação. Rio de Janeiro: Civilização Brasileira, 2003. p. 397-418.

CASTELO, Claudia. O modo português de estar no mundo. Porto: Afrontamento, 1999.

- Apresentação: memórias coloniais: práticas políticas e culturais entre a Europa e a África. Cadernos de Estudos Africanos, [S.l.], v. 9-10, 2006.

CHOMSKY, Noam. Timor-Leste, as vítimas que não valem a pena. Revista Adusp, [S.l.], outubro, 1999. Disponível em: < http://www.adusp.org.br/ files/revistas/18/r18a08.pdf>. Acesso em: 10 jun. 2017.

COMEMORAÇÕES 500 ANOS. Da afirmação da nova identidade tomorense. 13 de agosto de 2015. Disponível em: <https://

comemoracoes500anos.wordpress.com/noticias/>. Acesso em: 18 nov. 2015.

CORREIA, Rui. Lisboa - Dilli. 14 de julho de 2015. Disponível em: $<$ http://lisboa-dili.blogs.sapo.pt/rui-correia-7886>. Acesso em: 12 ago. 2016.

COSTA, Borja, Borja da Costa, Seleção de Poemas, Lisboa: Lidel, 2009.

CRISIS GROUP. Timor-Leste: Oecusse and the Indonesian Border. Policy Briefing, Asia Briefing, [S.l.], n. 104, Dili/Brussels; 20 May 2010.

Disponível em: <https://www.files.ethz.ch/isn/1 16501/B104\%20TimorLeste.pdf>. Acesso em: 2 jan. 2017.

DE LUCCA, Daniel. A Timorização do Passado: nação, imaginação e produção da história em Timor-Leste. 2016. Tese (Doutorado em Ciências Sociais ) - Universidade de Campinas, Unicamp, IFCH, 2016.

DURAND, F. História de Timor-Leste - Istória Timor-Leste Nian. Lisboa: Lidel, 2010. 
DUSSEL, Enrique. 1492: el encubrimiento del otro, hacia el origen del 'mito de la modernidad'. La Paz: Plural Editores y Universidad Mayor de San Andrés, 1994.

FIDALGO CASTRO, Alberto. A Religião em Timor-Leste a partir de uma perspectiva Histórico-Antropológica. In: NÁCHER, A. Léxico FatalucoPortuguês, Díli: AECID/Dom Bosco Timor-Leste, 2012.

FORUM HAKSESUK. Fatin HAKSESUK, dada-lia no hakerek kona ba Demokrasia, Politika, Sosial no Ekonomia iha Rai Timor - Leste. 27 de novembro de 2015. Disponível em: < http://forum-haksesuk.blogspot.com. br/2015/1 1/komemorasaun-tinan-500.html >. Acesso em: 2 jan. 2016.

FOX, James J. (Org.). The Flow of Life: essays in the Eastern Indonesia. Cambridge, EUA: Harvard University Press, 1980.

GEERTZ, Clifford, Negara: o Estado-Teatro no Século XIX. Rio de Janeiro: Bertrand,1991.

GONÇALVEZ, João Felipe. Revolução, voltas e reveses: temporalidade e poder em Cuba. Revista Brasileira de Ciências Sociais, [S.l.], v. 32, n. 93, fevereiro, 2017.

GUSMÃO, Xanana. Timor-Leste: um povo, uma pátria. Lisboa: Colibri; 1994.

HALL, Stuart. Quando foi o pós-colonial? Pensando no limite. In: HALL, Stuart. Da Diáspora: identidades e mediações culturais, Belo Horizonte: Humanitas, 2003. p. 101-128.

HOBSBAWM, Eric J. A Era dos Impérios 1875-1914. Rio de Janeiro: Paz e Terra; 1988.

JUGULAR. A propósito da morte de Mandela. Por Paulo Pinto em Paulo Pinto 6 de dezembor de 2013. Disponível em: < http://jugular.blogs. sapo.pt/3664372.html>. 12 ago. 2016.

LEGASPI BOUZA, Éfren. Oleu Pitine. In: NÁCHER, A. Léxico FatalucoPortuguês. Díli: AECID/Dom Bosco Timor-Leste, 2012. p. 41-78.

LEACH, Michael. East Timorese History after independence. History Workshop Journal, [S.l.], v. 61, n. 1, 2006.

L'ESTOILE, Benoîte de. The past as it lives now: an anthropology of colonial legacy. Social Anthropology/Anthropologie Sociale, [S.l.], v. 16, European Association of Social Anthropologists, 2008.

LUTZ, Melissa. Colonization, decolonization and integration: language politicies in East Timor, Indonesia. 1995. Disponível em: < http:// www.uc.pt/ Timor/language.htm>. Acesso em: 28 nov. 2001. 
MA'AVERU, Sávio, Timor-Leste: Kolonizasaum no Kruzamentu Kulturál, História e Literatura de Timor Lorosa'e, 2016. Disponível em: <http:// literatura-timor.blogspot.com.br/search/label/História\%20-\%20Tetum>. Acesso em: 2 ago. 2016.

MAESO, Silvia. O turismo e a academia da Idade dos Descobrimentos em Portugal: o silenciamento/reprodução do racismo no loop pós-colonial. Política \& Trabalho, [S.l.], n. 44, 2016.

MARY MARTINS BROKSELLERS. Tinan 500 Anos Year: Portugal Timor $=500$ Years Portugal - Timor. 2015. Disponível em: $<$ http:// www.marymartin.com/web/selectedIndex?mEntry=236533 > . Acesso em: 2 jan. 2016.

MCCLINTOCK, Anne, Pós-colonialismo e o anjo do progresso, In: MCCLINTOCK, Anne, Couro Imperial: raça, gênero e sexualidade no embate colonial, Campinas: Editora Unicamp, 2010. p. 15-40.

MONTERO, Paula; THOMAZ, Omar. (Org. ). Entre o mito e a história: o V Centenário do Descobrimento da América. Petrópolis: Vozes, 1996.

NOVAIS, Fernando A. A certidão de nascimento ou de batismo do Brasil. In: NOVAIS, Fernando A. Aproximações - estudos de história e historiografia, São Paulo: Cosac \& Naify; 2005.

OBSERVATÓRIO DA LÍNGUA PORTUGUESSA. Joaquim de Brito, autor do conceito e do design do monumento. 29 de novembro de 2015. Disponível em: <http://observalinguaportuguesa.org/joaquim-de-britodesigner-autor-do-conceito-do-monumento-e-do-design-do-nucleo-ecoracao-do-monumento-caravela-e-estatuas-de-descobridor-padre-portaestandarte-e-3-figuras-timorenses-inaugurado/> . Acesso em: 9 jan. 2015.

OLIVEIRA, Lucia Lippi. Imaginário histórico e poder cultural: as comemorações dos descobrimentos. Estudos Históricos, Rio de Janeiro, v. 14, n. 26, 2000.

PELISSIER, R. Timor em guerre: Le crocodile et les portugais (18471913). Orgeval: Ed. Pelissier, 1996.

PINTO, Paulo Jorge de Souza. Portugal em Malaca e no Mundo MalaioIndonésio. In: PEREZ, Rosa Maria (Coord.), Os Portugueses e o Oriente: história, itinerários, representações. Lisboa: Dom Quixote, 2006.

A Austrália descoberta pelos portugueses? Ficções aquém e além de capricórnio. Brotéria: Cristianismo e Cultura, [S.l.], v. 178, n. 5-6, 2014.

PRATT, Mary Louise, Os olhos do império: relatos de viagem e transculturação. Bauru: EDUSC; 1999. 
PRIMEIRO MINISTRO. Discurso de Sua Excelência o PrimeiroMinistro da República Democrática de Timor-Leste, Dr. Rui Maria de Araújo, por ocasião do jantar oferecido pela Comemoração do 40 Aniversário da Proclamação da Independência e dos 500 anos da interação de duas civilizações: Timor-Leste e Portugal e afirmação da Identidade Timorense. Oe-Cusse Ambeno, 27 de novembro de 2015. Disponível em: < http://timor-leste.gov.tl/wpcontent/uploads/2015/1 1/Jantar-de-Comemora\%C3\%A7\%C3\%A3o-do40\%C2\%BA-Anivers\%C3\%Alrio-da-Proclama\%C3\%A7\%C3\%A3o-daIndepend $\%$ C3\%AAncia-e-dos-500-anos-da-Intera\%C3\%A7\%C3\%A3o-deTimor-Leste-e-Portugal_27.11.2015.pdf>. Acesso em: 10 jun. 2017.

RÁDIO VATICANO. A voz do Papa e do Vaticano em diálogo com o mundo. Papa envia carta pelos $\mathbf{5 0 0}$ anos de evangelização do TimorLeste. 6 de agosto de 2015. Disponível em: <http://br.radiovaticana.va/ news/2015/08/06/papa_envia_carta_pelos_500_anos_de_evangelização_do_ timor-le/1 163448>. Acesso em: 12 out. 2016.

RAMOS-HORTA, José. Funu: the Unfinished saga of East. Timor: The Red Sea Press, 1987.

ROQUE, Ricardo, Headhunting and Colonialism: anthropology and the circulation of human skulls in the portuguese empire, 1870-1930. (Cambridge Imperial and Post-Colonial Studies Series), Basingstone: Palgrave McMillan, 2010.

. A Missão em Guerra: a história oculta da coleção de crânios de Timor da Universidade de Coimbra. Antropologia Portuguesa, [S.l.], v. 26-27, 2009.

ROSA, F. D. Uruvatju e Tjiapu: genealogias invisíveis da etnografia missionária em Timor-Leste. In: NÁCHER, A. Léxico FatalucoPortuguês. Díli: AECID/Dom Bosco Timor-Leste, 2012. p. 11-40.

SAPO24. 500 anos de laços entre Portugal e Timor-Leste mostram país sem preconceitos - Ramos-Horta. 25 novembro de 2015. Disponível em: <http://24.sapo.pt/noticias/internacional/artigo/500-anosde-lacos-entre-portugal-e-timor-leste-mostram-pais-sem-preconceitosramos-horta_20020343.html>. Acesso em: 2 jan. 2016.

\section{SAPONOTÍCIAS. Desenvolvimento de Timor-Leste começa em}

Oecússi, enclave onde nasceu o país. 13 de setembro de 2014. Disponível em: < http://noticias.sapo.tl/portugues/lusa/artigo/18213032. htm >. Acesso em: 11. nov. 2016.

SUARA-TIMOR-LOROSAE. Komemora Tinan 500 Prezensa Portugal, Governu Aloka Miliaun 1.5, Munisipiu 12 Hetan millaun 2.5. By STL Online November 16, 2015. Disponível em: < http://suara-timor-lorosae. $\mathrm{com} / \mathrm{s}=\operatorname{tinan}+500>$. Acesso em: 10 jul. 2016. 
SANTOS, Boaventura de Sousa. Entre próspero e Caliban: colonialismo, pós-colonialismo e interidentidade. Novos Estudos CEBRAP, [S.l.], n. 66, julho de 2003.

SCOTT, James C. The moral economy of the peasant. New Haven: Yale University Press, 1976.

SHOHAT, Ella; STAM, Robert, Crítica da Imagem Eurocêntrica. São Paulo: COSAC \& NAIFY, 2006.

SILVA, Ricardo Jerônimo. Portugal dos Pequenitos: a cristalização de um império ou brincadeira de crianças? Midas, [S.l.], n. 6, 2016.

SILVA, Kelly. A nação Cordial: uma análise dos rituais e das comemorações e das ideologias oficiais de comemoração dos 500 anos do Brasil. Revista Brasileira de Ciências Sociais, [S.l.], v. 18, n. 51, fevereiro, 2003.

- A bíblia como constituição ou a constituição como bíblia?

Projetos para a construção do Estado-nação em Timor-Leste. Horizontes Antropológicos, Porto Alegre, ano 13, n. 27, jan.-jun. 2007.

SUBRAHMANYAM, Sanjay, Impérios em concorrência: histórias conectadas nos séculos XVI e XVII. Lisboa: ICS, 2012.

TAMBIAH, Stanley. Culture, thought and social action: an anthropological perspective. Cambridge; Harvard University Press, 1985.

THOMAZ, Luís Filipe F. R. De Ceuta a Timor. Lisboa: Instituto Camões, 1994.

. Babel Lorosa'e: o problema linguístico de Timor- Leste. Lisboa: Instituto Camões, 2002.

THOMAZ, Omar Ribeiro. Ecos do Atlântico: Representações sobre o Terceiro Império Português. Rio de Janeiro: editora UFRJ/FAPESP, 2002.

TIMOR 500 ANOS. Da chegada das caravelas. Novembro de 2015. Disponível em: < http://timor500anos.blogs.sapo.tl/13970.html>. Acesso em: 12 ago. 2016.

TRAUBE, Elizabeth. Cosmology and Social Life: ritual exchange among the Mambai of East Timor. Chicago \& London: University of Chicago Press, 1986.

TROUILLOT, Michel-Rolph. Silencing the Past: Power and the Production of History. Boston: Beacon Press, 1995.

UM LIVRO, UM AMIGO PARA TIMOR. 16 de janeiro de 2016. Disponível em: <https://www.youtube.com/watch?v=l0QjNPN-wFc $>$. Acesso em: 11 nov. 2016.

Recebido em 02/08/2017

Aceito em 04/10/2017 